\title{
Biomass production and characteristics of short rotation plantations of clones of Gmelina arborea in three spacings
}

\author{
Carolina Tenorio', Roger Moya ${ }^{2 *}$, Juan Carlos Valverde³, Dagoberto Arias-Aguilar ${ }^{4}$
}

\begin{abstract}
${ }^{1}$ Instituto Tecnológico de Costa Rica; Escuela de Ingeniería Forestal; Apartado Postal: 159-7050 Cartago-Costa Rica; Teléfono: (506) 2550-2223/ Fax: (506) 591-3315; ctenorio@itcr.ac.cr, ORCID: https://orcid.org/0000-0003-2901-7079 ${ }^{2}$ Instituto Tecnológico de Costa Rica; Escuela de Ingeniería Forestal; Apartado Postal: 159-7050 Cartago-Costa Rica; Teléfono: (506)2550-9092/Fax: (506) 591-3315; ORCID: https://orcid.org/0000-0002-6201-8383

${ }^{3}$ Instituto Tecnológico de Costa Rica; Escuela de Ingeniería Forestal; Apartado Postal: 159-7050 Cartago-Costa Rica; Teléfono: (506)2550-2288/Fax: (506) 591-3315; jcvalverde@itcr.ac.cr. ORCID: https://orcid.org/0000-0002-3181-1346 ${ }^{4}$ Instituto Tecnológico de Costa Rica; Escuela de Ingeniería Forestal; Apartado Postal: 159-7050 Cartago-Costa Rica; Teléfono: (506)2550-2279/Fax: (506) 591-3315; daguilar@itcr.ac.cr. ORCID: https://orcid.org/0000-0002-3056-9172
\end{abstract}

*Corresponding author: Roger Moya, Email: rmoya@itcr.ac.cr

\begin{abstract}
The first attempts to establish energy crops in the tropical region using short rotation species are premised on the utilization of clones for wood production. Therefore, the present study is aimed at examining the growth aspects (survival, diameter and tree height), leaf architecture (leaf area index [LAI], number and angle of the branches and sylleptic branches), biomass production, as well as biomass flow at the age of 24 months of two clones of Gmelina arborea in short rotation crops within three spacings $(1.0 \times 1.0 \mathrm{~m}, 0.75 \times 0.75 \mathrm{~m}$ and $1.0 \times 0.5 \mathrm{~m})$. The results showed an increment with age, as the diameter increased from $3.00 \mathrm{~cm}$ at six months to $8.0 \mathrm{~cm}$ at 24 months, whereas the total height increased from $2.00 \mathrm{~m}$ at six months to 10.00 $\mathrm{m}$ at 24 months. Clone survival varied from 20 to $60 \%$, whereas the LAI, branch angle and sylleptic branches increased with age. The differences between clones appeared after 12 months. Biomass production was similar between clones, from 6 ton/ha at six months to 67 ton/ha at 24 months, with clone 2 showing greater biomass flow than clone 1. On the basis of biomass production results and the development of diameter as well as height, clone 1 is recommended for spacing $1.0 \times 1.0 \mathrm{~m}$ and clone 2 for spacings $0.75 \times 0.75 \mathrm{~m}$ and $1.0 \times 0.5 \mathrm{~m}$.
\end{abstract}

Keywords: fast growth; tropical species; plantation density; woody crops, energy crops.

\section{Introduction}

The high prices of fossil fuels worldwide, in conjunction with increasing environmental problems, had facilitated the creation of policies to promulgate the use of renewable energy (Inglesi-Lotz, 2016). In this sense, biomass had been an important renewable and environmentally-friendly source of energy (Pleguezuelo et al., 2015). According to Cerda et al. (2008), solid biomass includes woody biomass from short rotation systems (short rotation woody crops, SRWC) and residues coming from forests or forest plantations (such as cleaning and pruning residues), agricultural residues and residues from forest industries (sawdust, slabs, etc.).

SRWC assume great significance because these are systems wherein fast growing tree species are cultivated under intensive agricultural practices in order to achieve high biomass yield (Pleguezuelo et al., 2015). The SRWC had assumed importance in some countries of the European Union (Schulze et al., 2016) and in the United States (Djomo et al., 2015). SRWC has also elicited an increasing amount of attention in Chile (Carmona et al., 2015), Brazil (Junior et al., 2016) as well as in some Central American countries (Cutz, et al., 2016; SalazarZeledón et al., 2015). However, the establishment of SRWC had not been studied adequately (Moya et al., 2019).

In the context of Costa Rica, Tenorio et al. (2016 and 2018) reported the first findings from SRWC using Gmelina arborea trees (gambar in Asia and melina or gmelina in America), stating that the spacings $0.5 \times 1.0 \mathrm{~m}(20000 \mathrm{~N} / \mathrm{ha})$ and $1.0 \times 1.0 \mathrm{~m}$ (10 $000 \mathrm{~N} / \mathrm{ha}$ ), showed the highest production (ton/ha) during the first two years of growth and the best biomass 
characteristics as compared to the spacing $2.0 \times 1.0 \mathrm{~m}(5000 \mathrm{~N} /$ ha). These authors also pointed out that the site was a critical factor for biomass production and that the characteristics of trees growing under SRWC systems varied considerably from one year to another.

The development of clonal reforestation programs is a practical and effective strategy for increasing productivity of the plantations is (Li et al., 2017). Various authors have studied the uses of clones in the establishing of SRWC whereas some of the most frequently utilized genera are Populus spp (Fang et al., 1999; Paris et al. 2011), Salix spp (Stolarski et al., 2011) and Eucalyptus spp (Souza et al., 2015; Eufrade Junior et al., 2016). A characteristic that is common to the development of clones of these species in SRWC was that these clones are sourced from reforestation programs that focus on wood production or pulp industries (Zamora et al., 2015). After conducting a study for six years of Populus clones used for sawlog production but planted in SRWC, Fang et al. (1999) concluded that the most productive clones need to be resistant to diseases and insect pests, adjust to the site conditions, and plant techniques characterized by high competition caused by narrow spacing.

On the other hand, Gmelina arborea is a highly important species for commercial reforestation in tropical countries. In Central America, G. arborea grows in sites with divergent levels of precipitation and temperature as well as in soils with adequate calcium levels (Arguedas et al., 2018). In the case of Costa Rica, G. arborea had been planted in a variety of sites, where tree growth rates currently allow for rotations less than 10 years (Vallejos et al., 2017). Traditionally, G. arborea has been used to produce woods at densities ranging from 600-1200 N/ ha in order to obtain wood for the pallet market (Lansing, 2013).

Currently, the development of programs for genetic improvement allows for the reduction of initial planting density down to $625 \mathrm{~N} / \mathrm{ha}$ (Serrano and Moya, 2011) and obtains production levels above $30 \mathrm{~m}^{3}$ ha $^{-1}$ year-1 with rotations between six and eight years (Ávila-Arias et al., 2015). These programs of commercial reforestation have a series of clones suitable for sawlogs, which, in turn, have focused on the development of the trees' morphological characteristics and the production in volume per hectare (Ávila-Arias et al., 20162015; Murillo et al., 2018). However, currently, there are no data on the use of these clones in narrow spacings as those used in SRWC for energy purposes.

Within this context, the objective of the present study was to evaluate survival, diameter at the tree base and the total height of trees, leaf area architecture (leaf area index [LAl], quantity and angle of the branches and sylleptic branches), leaf biomass production, and biomass production of two clones of Gmelina arborea for wood production during the first 24 months (of age) in SRWC systems at three spacings (1.0x1.0 m, $0.75 \times 0.75 \mathrm{~m}$ and $1.0 \times 0.5 \mathrm{~m}$ ). On the basis of this information, we intended to identify the biomass production potential of two clones used in wood production, albeit evaluated in SRWC spacings.

\section{Materials and Methods}

\section{Geographic location and conditions of the planta- tion}

The work was conducted in an energy plantation of two clones of Gmelina arborea located in Santa Rosa of Pocosol, Alajuela, Costa Rica. The clones used in this plantation presented greater diameter growth and higher sawlog production when planted for wood production. Meanwhile the clones were derived from F1 selection of trees growing in fast-growth plantation located in the Northern part of Costa Rica, whereas the clonal selection was developed over the last ten years (Murillo et al., 2018). Three types of spacings along with three repetitions were employed (1.0x1.0 m [10 $000 \mathrm{~N} / \mathrm{ha}], 0.75 \times 0.75 \mathrm{~m}$ [17500 $\mathrm{N} / \mathrm{ha}$ ] and $1.0 \times 0.5 \mathrm{~m}$ [20000 N/ha]) for each clone. Therefore, 18 experimental units were sampled (2 clones $x 3$ spacings $x 3$ repetitions $=18$ experimental units). The area of each experimental unit was $200 \mathrm{~m}^{2}$, where 200, 355 and 400 trees were planted established for $1.0 \times 1.0 \mathrm{~m}, 0.75 \times 0.75 \mathrm{~m}$ and $1.0 \times 0.5 \mathrm{~m}$, respectively. The site where SWRC was established presents an average temperature between $22-25{ }^{\circ} \mathrm{C}$, an annual average precipitation ranging between 2600 and $3500 \mathrm{~mm} /$ year, and a dry season between the month of January and April with almost $0 \mathrm{~mm}$ of precipitation. Meanwhile the soil texture was sandy loam to loam, whereas the color was dark yellow-brown. The soil is volcanic in origin with alluvial material overlying lateritic deposits (Krebs, 1975).

\section{Tree sampling in the plantation and sampling in the tree}

The sampling took place at four different ages: 6, 12, 18 and 24 months. Firstly, at each age the quantity of trees (individual trees, not tillers) present in the experimental units were counted in order to determine the survival of each clone in different spacing conditions. Then, five trees were sampled in each experimental unit ( 2 clones $\times 3$ spacings $\times 3$ blocks $\times 5$ trees $=$ 90 trees), measuring diameter at $30 \mathrm{~cm}$ from the ground level and total height. Subsequently, the trees were cut at the ground level and the leaves were separated, thus leaving the trunk and the branches. In this condition, the total height, the total number of branches in the trunk, as well as the angles of five branches was measured. Each part of the tree (leaves, branches and trunk) was weighed independently using a 0.01 $\mathrm{kg}$ weighing scale. Next, six cross sections $10 \mathrm{~cm}$ long were cut at three different heights: two samples at the base of the tree, two samples at the total tree height and two samples at $50 \%$ total tree height. Then, approximately 500 grams of leaves plus 500 grams of branches was taken from each one of the trees. The remaining material from the trunk was grinded in order to obtain pieces no bigger than $3 \mathrm{~mm}$ long.

\section{Determination of the leaf area index and branch characterization}

The leaf area index (LAl) was determined by means of a nondestructive method, following the methodology proposed by 
Mason et al. (2012). For this purpose, the leaves of the sampled trees of each clone were separated and weighed in green condition; subsequently, a 500 grams sample was taken from the crown and the leaves were then extended on a black surface, before beig photographed at $450 \mathrm{dpi}$ to calculate the specific leaf area (SLA) and the ratio weight-SLA. Lastly, the LAI was calculated using the weight-SLA determined and multiplied by the total leaf weight of the sample tree.

With regard to the number of branches, this parameter was expressed as the quantity of branches per linear meter. However, branches (number, angle and types) are genetic traits that are directly related to wood production. Recently, an interesting study was conducted to study the traits of branches in trees growing in SRWC systems for increasing biomass yield (Alcorn et al., 2007; DeBell et al., 1996). The branches of each tree were counted and the result was divided by the tree's total height. Concerning branch angles, the measurement was performed in the upper part of the individual's living crown (Weiss et al., 2004). Five branches were randomly selected and the inside angle of each branch was measured using a digital $0.5^{\circ}$ error triangle. Thereafter, the average per clone was obtained. Finally, the number of sylleptic branches per meter was estimated. Sylleptic branches appeared immediately in a lateral axis before the apical meristem had had a period of intermediate rest (Benomar et al., 2012). Sylleptic branches were then visually determined and counted by sampling five branches of the upper crown; in this manner, the percentage of sylleptic branches was determined and this quantity was extrapolated as per linear meter based on the quantity of branches per meter in each clone.

\section{Biomass determination and distribution}

Firstly, the moisture content (MC) of the biomass was measured. The 500 grams sample of each one of these parts was used to determine the MC of the leaves and branches. Both samples were weighed in a green condition and placed into an oven at $103{ }^{\circ} \mathrm{C}$ for 24 hours, subsequent to which period the samples were weighed again. The $\mathrm{MC}$ was calculated by the ratio of water relative to the green weight $\left(M C=100^{*}\right.$ [weight before drying - weight after drying]/weight before drying). In order to obtain the MC of the trunk and the bark, the $10 \mathrm{~cm}$ samples taken at three different heights, after separating the bark from the trunk. Both parts were dried in an oven at $103^{\circ} \mathrm{C}$ for a period of 24 hours. The weight before and after drying was determined and then used to calculate the MC using the aforementioned percentage ratio. The quantity of biomass of the total trunk (Equation 1) was determined using the trunk $M C$ and the trunk weight in green condition. Likewise, the weight of the totality of leaves and branches after drying was used to calculate the biomass of each part. The biomass of the trunk, leaves, and branches was used to calculate the distribution of the percentage of biomass for each part of the tree. Then, the biomass values were projected to calculate the biomass per hectare for each plantation spacing $(1.0 \times 1.0 \mathrm{~m}, 0.75 \times 0.75 \mathrm{~m}$ and $1.0 \times 0.5 \mathrm{~m})$.

Dry biomass $=$ Green weight ${ }_{\text {part of the tree }\left(1-\frac{M C_{\text {part of the tree }}}{100}\right)}$

\section{Quantification of biomass by leaf fall patterns}

Five trees were randomly selected in each experimental unit and a mesh approximately $1 \mathrm{~m}^{2}$ was placed at the base of each tree, as a trap to collect the falling leaves. However, with an increase in the age of tree, it was necessary to expand the area of the leaf trap in order to collect all the falling leaves. Leaf collection was performed on a monthly basis. The leaves were dried in a kiln at $103^{\circ} \mathrm{C}$ for 24 hours before being weighed. This weight represented the biomass eliminated by the tree in a month, or biomass flow. These values were not extrapolated to hectares because the tree mortality occurred during the year, which prevented the collection of precise data. Therefore, the value of biomass was maintained in grams/tree. Subsequently, the biomass flow in time was calculated for each month evaluated throughout the 24 months for each spacing, along with the amount of biomass in the four periods of evaluation: 6,12 , 18 and 24 months per spacing.

\section{Statistical analysis}

Compliance of the measured variables with the assumptions of the normal distribution, homogeneity of the variances, and the presence of outliers was verified. An analysis of variance was then applied in order to veryify the effect of the clone as well as the different planting spacings in each age at which the clones were evaluated. The clone, spacing and its interrelation, and the measured variables (diameter, height, MC, biomass of the different parts, LAl, number and angle of branches and sylleptic branches) as response variables were used as the model's independent variables. In addition, Tukey's test was used in order to determine the statistical differences between the means of the measured variables. The analysis of variance and Tukey's test was then performed using SAS software (SAS Institute Inc., Cary, NC).

\section{Results and Discussion}

\section{Height and diameter growth}

Trees' diameter and height was found to increase with age (Figure 1a-b). Increments of tree diameter and height increments with age correspond to the normal development of the trees in their first years, since the tree grows to gain position in height first before starting to develop in diameter (Ryan and Yober, 1997). Differences between the clones were observed at some ages and in most spacings for diameter. Interestingly, diameter in clone 1 was found to be higher than clone 2 in $1.0 \times 1.0 \mathrm{~m}$ at 6 and 24 months and no statistical differences were observed between clones at 12 and 18 months within the same spacing (Figure 1a). Clone 2 presented higher diameter than clone 1 for spacing of $0.75 \times 0.75 \mathrm{~m}$. Meanwhile in spacings $1.0 \times 0.5 \mathrm{~m}$, clone 2 showed a higher diameter than clone 1 at 12 and 18 months, but no statistical difference was found at 6 and 24 months (Figure 1a). With respect to height, differences between the clones were observed in spacing $1.0 \times 1.0 \mathrm{~m}$ at 6 and 18 months as well as in spacing $0.75 \times 0.75 \mathrm{~m}$ at 6 and 24 months 
(Figure 1b). An improved development in diameter of clone 1 was observed at the ages of 6 and 24 months (Figure 1a), and in height at the ages of 6 and 18 months (Figure $2 b$ ) in spacing $1.0 \times 1.0 \mathrm{~m}$. Meanwhile clone 2 exhibited greater diameter (better development) in the closer spacings $0.75 \times 0.75 \mathrm{~m}$ and $1.0 \times 0.5 \mathrm{~m}$ at the ages of 12,18 and 24 months (Figure 1a). Although the below results can affirm that clone 1 is indeed adaptable for wider spacing and clone 2 for narrower spacing, it needs to be pointed out that the differences were influenced by survival (Figure 1c). In case of a high level of survival, the tree presented minor diameter and minor height.

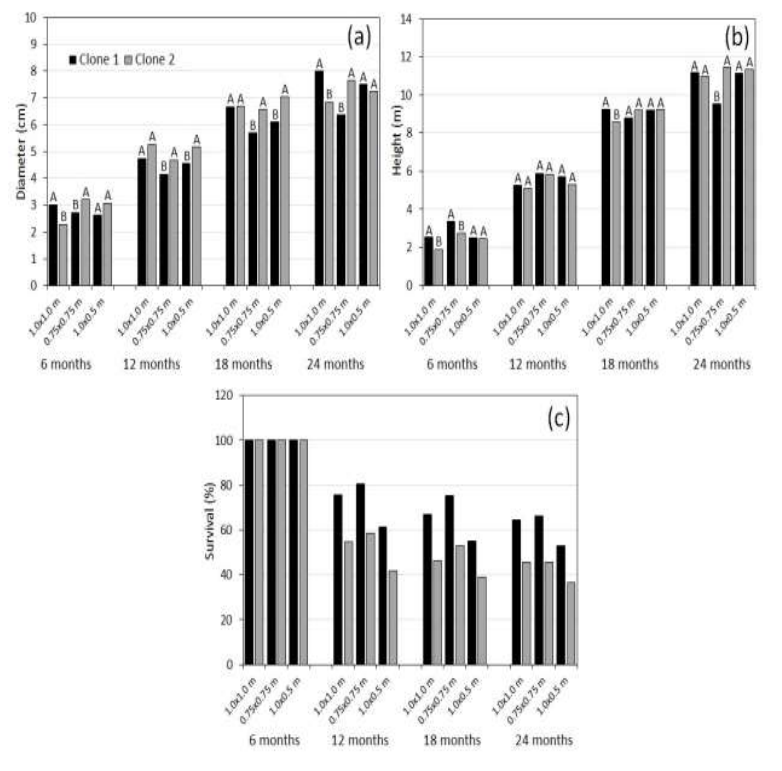

Figure 1

Average diameter (a), height (b) and survival (c) by age and spacing of two clones of Gmelina arborea growing in a short rotation system.

Note: Survival is a function of the initial density. Different letters indicate statistical differences at $95 \%$ of confidence between spacings.

The differences in diameter and height development of each clone in the various spacings were linked to the clone's ability to adapt to various conditions of competition (Zamora et al., 2015). In this regard, DeBell et al. (1996) remarked that some clones are genetically prepared for more severe conditions of competition, as evidenced in the narrow spacings in clone 2 $(0.75 \times 0.75 \mathrm{~m}$ and $1.0 \times 0.5 \mathrm{~m})$. This clone probably developed physiological processes that were able to adapt better to the conditions of competition present within narrow spacings (Carmona et al., 2015). On the other hand, clone 1 was physiologically more prepared for low competition, as in spacing 1.0 $\mathrm{x} 1.0 \mathrm{~m}$, where it exhibited better height and diameter growth.

\section{Survival/mortality}

Importantly, lower tree survival was observed between 6 and 12 months for both clones. However, the level of survival of clone 1 was higher as compared to clone 2 for the three applied spacings (Figure 1c). For this period as well as for clone 1, survival percentages of $76 \%, 81 \%$ and $61 \%$ were observed, while the percentages were of $55 \%, 58 \%$ and $42 \%$ for spacings $1.0 \times 1.0 \mathrm{~m}, 0.75 \times 0.75 \mathrm{~m}$ and $1.0 \times 0.5 \mathrm{~m}$, respectively for clone 2 (Figure 1c). At 24 months, the percentage of survival of the trees concerning the initial planting density was of $64 \%, 66 \%$ and $53 \%$ for clone 1 , and of $46 \%, 46 \%$ and $37 \%$ for clone 2 , in spacings $1.0 \times 1.0 \mathrm{~m}, 0.75 \times 0.75 \mathrm{~m}$ and $1.0 \times 0.5 \mathrm{~m}$, respectively (Figure 1c).

The conditions of the soil in the site where the SRWC system was established produced high mortality, therefore tree survival was low (Figure 1c), probably the tree needed for resources in the spacings applied (Paris et al, 2011). Tree mortality can be explained by taking different aspects into consideration (Paris et al., 2011). The first aspect was demand for resources. After establishing the plantation, the tree starts to grow until reaching the maximum resource availability the site can be supported after a given period (Onyekwelu et al., 2003). However, the growth was limited once competition among the trees begins (DeBell et al., 1996), subsequent to which, resource release through mortality occurred (Hall, 1994). The second aspect was pertaining to the amount of resources in the soil, upon which tree survival depends on (Laureysens et al., 2004). Competition was found to be greater in sites that lack the necessary resources for tree growth, which leads to the mortality of some individuals (Dillen et al., 2013).

With regard to the percentage of survival of the clones, it was higher in clone 1 than in clone 2. Clone 1 was found more adaptale to survive in SRWC conditions, which was expected since some clones were genetically better suited for competing conditions (Zamora et al., 2015). Despite this condition, survival was low in both clones, between 20 and $60 \%$, which probably implies that these clones were not appropriate for SRWC at the plantation's site. However, it does not necessarily mean that the same clones will exhibit better survival and production in other sites. According to Dillen et al. (2013), breeding and selection for SRC is a complex process; in addition to seeking fast growth rates, also importance is also attached to sustaining biomass yields and an ability to survive. Meanwhile the other traits that are usually considered in breeding programs for biomass bioenergy production include the ability to coppice, wood composition (lignin), and elemental content, among others biomass characteristics (Li et al., 2017).

The results of the present study were found to be similar to those of other studies in other regions of Costa Rica. To illustrate, Tenorio et al. (2019) reported a survival percentage between 60 and $77 \%$ after reaching the age of two years, which was similar to the values found for clone 1 (Figure 1c). The same authors pointed out that the site's fertility was important for the establishment of the SRWC of G. arborea since some of the sites analyzed in Costa Rica showed a survival rate of $95 \%$ towing to good site conditions.

Crown characteristics: Leaf area index, leaf biomass and branch characterization (frequency and biomass of total branches and sylleptic branches) 
As expected, the LAI per tree increased with age, with clone 2showing higher values than clone 1 (Figure 2a), except at six months in spacings $1.0 \times 1.0 \mathrm{~m}$, where no differences were observed between the clones (Figure 2a). Figure $2 \mathrm{~b}$ shows clearly the difference in color of the crown of the clones in each block. The crowns in clone 2 are more intensely colored than the crowns in clone 1.
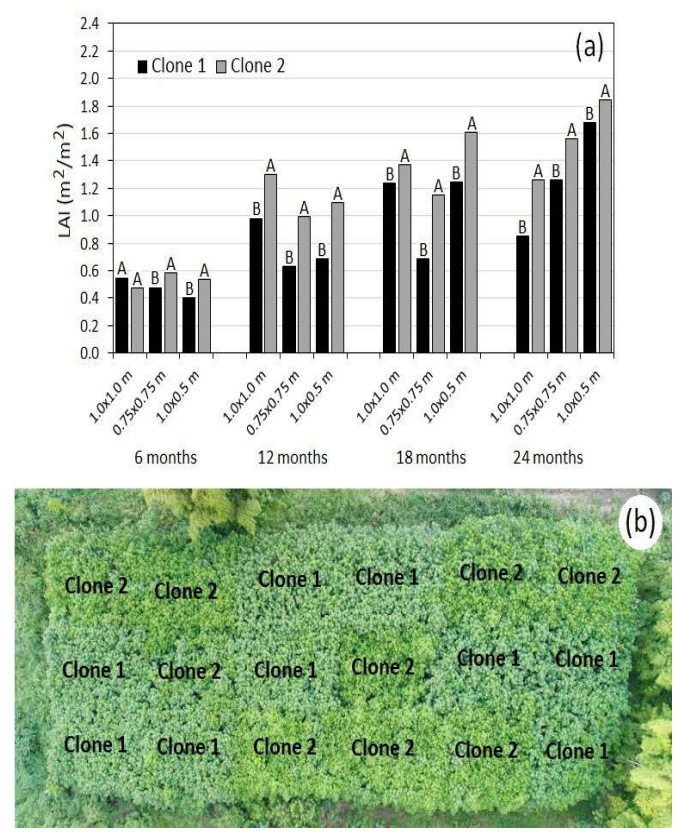

Figure 2

Leaf area variation per tree, per age and spacing (a) and aerial aspect of the experimental units of the two clones of Gmelina arborea growing in a short rotation system at the age of 18 months (b).

Note: Different letters indicate statistical differences at $95 \%$ of confidence between spacings.

Regarding branch angle (Table 1), it increased with age in the widest spacing $(1.0 \times 1.0 \mathrm{~m})$. In spacing $0.75 \times 0.75 \mathrm{~m}$, the branch angles kept stable at $54^{\circ}$ between 6 and 18 months, increasing to approximately $58^{\circ}$ at the age of 24 months. Up to the age of 12 months, the branch angles remained stable in the spacing $1.0 \times 0.5 \mathrm{~m}$, revealing a tendency to decrease as the age increases. After 12 months, the branch angles showed a decrease as the spacing diminished, with greater changes being observed with an increase in the age of plantation. Differences between clones regarding branch angle were observed only in spacing $0.75 \times 0.75 \mathrm{~m}$ at 12 months and in spacing $1.0 \times 1.0 \mathrm{~m}$ at the age of 24 months (Table 1).

As for branch frequency per meter at 24 months a slight increment occurred in the quantity of branches, especially in spacings $0.75 \times 0.75 \mathrm{~m}$ and $1.0 \times 0.5 \mathrm{~m}$, without evidence of statistical differences between clone 1 and clone 2 (Table 1). With regard to sylleptic branches, a slight increase in frequency was observed with an increase in age, along with some differences between the clones: clone 1 presented higher quantity of sylleptic branches at the age of six months and in spacing $1.0 \times 1.0$ $\mathrm{m}$, whereas at 6,12 and 18 months in spacing $1.0 \times 0.5 \mathrm{~m}$, the frequency of sylleptic branches was found to be lower in clone 1 (Table 1). Likewise, the frequency of sylleptic branches lowered with decreasing spacing at the different ages in clone 1 as well as in clone 2.

Leaf and branch biomass (ton/ha) increased with an increasing age of plantation as well as with decreasing spacing between trees. In terms of the differences between clones, clone 2 showed higher leaf biomass values at six months in spacing $0.75 \times 0.75 \mathrm{~m}$ and $1.0 \times 0.5 \mathrm{~m}$, and at 12 months in spacing $0.75 \times 0.75 \mathrm{~m}$ (Table 1), while no statistical differences were observed between the clones in the rest of the conditions. Regarding branch biomass (ton/ha), differences were observed at in the age of six months in spacing $0.75 \times 0.75 \mathrm{~m}$, where clone 1 showed the highest biomass value, at 12 months in spacings $0.75 \times 0.75 \mathrm{~m}$ and $1.0 \times 0.5 \mathrm{~m}$, and at 24 months in all spacings, where clone 2 exhibited the highest statistical biomass values (Table 1 ).

The crown parameters evaluated (LAI and branch characteristics) are attributed to the age of the plantation, the spacing, and the clone type, particularly at the onset of competition among trees after the age of six months (Table 1, Figure 2). These results agreed with the reports found in Benomar et al. (2012), Alcorn et al. (2007) and Henskens et al. (2001). Notably, Benomar et al. (2012) and Roeh and Maguire (1997) suggested that the structure, shape and abundance of the crown occurred in the tree as a direct effect of the its ability and efficiency to use the light, which was related to the age of the tree, space between trees, and the genetic disposition of the tree to these two factors.

SRWC's productivity was determined by light interception and the efficient use of radiation to produced biomass (Schwerz et al., 2019). In turn, the ability of the crop to intercept radiation was determined by its photosynthetic area, usually evaluated by means of the LAl, which was directly related to biomass production in plantations (Taylor et al., 2001). This confirms the increased leaf biomass production as the LAl increases with age (Table 1) and an increase in the amount of leaf biomass in clone 2, where LAl is greater (Figure 3a), especially in wider spacings (Table 2).

The architecture, distribution, and biomass of the branches was primarily influenced by age and spacing (Table 1), which was confirmed in several species planted in SRWC systems (Alcorn et al., 2007; DeBell et al., 1996; Henskens et al., 2001). Tree canopy characteristics determine the ability to capture light and perform photosynthesis so as to convert these resources into biomass (Roeh and Maguire, 1997; Wang and Jarvis, 1990). The differences in branch angles between spacings appeared after a period of 12 months; the branches developed normally in the absence of competition at early ages, but change in the crown architecture occurred when the competition begins (Benomar et al., 2012; Hegazy et al., 2008). With narrow spacing, the trees soon started to compete, as a result of which the branch angles diminished in search of heightened light interception (Benomar et al., 2012). 
However, no differences were observed between the clones regarding branch angles or branch frequency (Table 1), whereas differences did show with regard to the frequency of sylleptic branches (Table 1) and branch biomass (Table 1). The variation in the angle and frequency of branches is a strategy of the tree to optimize leaf development, thus increasing the tree's synthesis capacity to overcome the competition created by the spacing (Benomar et al., 2012). This is a sample of the plasticity of these parameters to achieve greater light capture efficiency (Ceulemans et al., 1990). With regard to this behavior, both types of clones were similar.

The weight increase of leaf biomass resulted from the need of the tree for greater light interception capacity as it ages and as the spacing diminishes, also due to increased disposition for biomass production (Benomar et al., 2012). However, the differences in leaf biomass quantity tended to disappear as the tree aged (Table 1). According to several reports on SRWC, leaf biomass decreased as the availability of nitrogen diminished in the soil (Hegazy et al., 2008), which could happen between the age of 18 and 24 months as this nutrient probably becomes exhausted. Initially, at a period of six to 12 months, the soil offered fertility to potentiate the characteristics of each clone, as was the case with clone 2 , which exhibited greater biomass at those ages (Table 1).

Table 1

Branch angles and frequency and sylleptic branches frequency in trees of two clones of Gmelina arborea per age and spacing in short rotation systems.

\begin{tabular}{|c|c|c|c|c|c|c|}
\hline $\begin{array}{l}\text { Tree age } \\
\text { (months) }\end{array}$ & $\begin{array}{l}\text { Spacing } \\
(\mathrm{m})\end{array}$ & Clone & $\begin{array}{c}\text { Angle } \\
\text { (degrees) }\end{array}$ & $\begin{array}{c}\text { Frequency of } \\
\text { branches } \\
(\mathrm{N} / \mathrm{m})\end{array}$ & $\begin{array}{c}\text { Frequency of } \\
\text { sylleptic } \\
\text { branches } \\
(\mathrm{N} / \mathrm{m})\end{array}$ & $\begin{array}{l}\text { Leaf biomass } \\
\text { (ton/ha) }\end{array}$ \\
\hline \multirow{6}{*}{6 months } & \multirow{2}{*}{$1.0 \times 1.0$} & 1 & $54.89^{A}(6.6)$ & $6.67^{A}(25.1)$ & $1.93^{A}(45.7)$ & $2.59^{A}(0.78)$ \\
\hline & & 2 & $54.50^{A}(6.0)$ & $6.07^{A}(14.6)$ & $0.87^{8}(85.8)$ & $2.17^{A}(0.22)$ \\
\hline & \multirow{2}{*}{$0.75 \times 0.75$} & 1 & $54.87^{A}(3.7)$ & $6.47^{A}(18.4)$ & $1.33^{A}(54.3)$ & $3.14^{A}(0.09)$ \\
\hline & & 2 & $54.95^{\mathrm{A}}(3.7)$ & $6.07^{A}(20.2)$ & $1.60^{A}(61.6)$ & $4.38^{B}(0.17)$ \\
\hline & \multirow{2}{*}{$1.0 \times 0.5$} & 1 & $54.63^{A}(4.6)$ & $5.73^{A}(21.3)$ & $1.13^{A}(73.6)$ & $3.04^{A}(0.47)$ \\
\hline & & 2 & $54.58^{A}(3.5)$ & $6.40^{A}(16.5)$ & $2.27^{8}(39.0)$ & $5.67^{8}(0.64)$ \\
\hline \multirow{6}{*}{12 months } & \multirow{2}{*}{$1.0 \times 1.0$} & 1 & $58.74^{A}(3.1)$ & $6.00^{A}(17.8)$ & $1.33^{A}(67.5)$ & $2.89^{A}(0.31)$ \\
\hline & & 2 & $58.83^{\mathrm{A}}(4.1)$ & $6.20^{A}(15.2)$ & $1.47^{A}(35.2)$ & $2.72^{A}(0.32)$ \\
\hline & \multirow{2}{*}{$0.75 \times 0.75$} & 1 & $54.32^{A}(4.2)$ & $5.87^{A}(16.9)$ & $1.60^{A}(51.8)$ & $3.20^{A}(0.32)$ \\
\hline & & 2 & $52.75^{\mathrm{B}}(3.5)$ & $6.27^{A}(12.7)$ & $1.67^{A}(43.4)$ & $3.83^{B}(0.02)$ \\
\hline & \multirow{2}{*}{$1.0 \times 0.5$} & 1 & $54.23^{\mathrm{A}}(3.0)$ & $6.00^{A}(12.6)$ & $1.40^{A}(36.2)$ & $3.16^{A}(0.93)$ \\
\hline & & 2 & $53.43^{A}(4.2)$ & $6.27^{A}(15.3)$ & $2.33^{\mathrm{B}}(41.8)$ & $3.46^{A}(0.47)$ \\
\hline \multirow{6}{*}{18 months } & \multirow{2}{*}{$1.0 \times 1.0$} & 1 & $64.73^{A}(2.3)$ & $5.33^{A}(16.9)$ & $2.60^{A}(24.3)$ & $2.92^{A}(0.57)$ \\
\hline & & 2 & $65.69^{A}(4.3)$ & $5.40^{A}(18.3)$ & $2.53^{A}(20.4)$ & $2.70^{A}(0.23)$ \\
\hline & \multirow{2}{*}{$0.75 \times 0.75$} & 1 & $54.97^{\AA}(2.9)$ & $6.13^{A}(16.1)$ & $1.80^{A}(43.0)$ & $3.21^{\mathrm{A}}(1.38)$ \\
\hline & & 2 & $54.17^{A}(2.2)$ & $6.27^{A}(15.3)$ & $2.13^{A}(30.0)$ & $3.82^{A}(0.17)$ \\
\hline & \multirow{2}{*}{$1.0 \times 0.5$} & 1 & $51.68^{A}(2.5)$ & $6.73^{A}(16.3)$ & $2.07^{A}(42.8)$ & $2.75^{A}(1.07)$ \\
\hline & & 2 & $50.30^{A}(2.3)$ & $7.00^{A}(12.1)$ & $2.87^{B}(31.9)$ & $4.04^{A}(1.68)$ \\
\hline \multirow{6}{*}{24 months } & \multirow{2}{*}{$1.0 \times 1.0$} & 1 & $73.18^{A}(3.9)$ & $5.33^{A}(19.6)$ & $2.93^{A}(20.2)$ & $2.73^{A}(0.97)$ \\
\hline & & 2 & $69.81^{B}(4.3)$ & $6.40^{A}(15.4)$ & $2.60^{A}(19.5)$ & $3.12^{A}(1.97)$ \\
\hline & \multirow{2}{*}{$0.75 \times 0.75$} & 1 & $58.11^{A}(1.5)$ & $6.93^{A}(13.9)$ & $2.07^{A}(22.1)$ & $2.81^{A}(0.93)$ \\
\hline & & 2 & $57.96^{A}(2.2)$ & $7.00^{A}(17.1)$ & $2.27^{A}(26.2)$ & $4.27^{A}(1.54)$ \\
\hline & \multirow{2}{*}{$1.0 \times 0.5$} & 1 & $47.78^{A}(4.3)$ & $8.47^{A}(16.0)$ & $2.07^{A}(34.1)$ & $3.32^{A}(0.46)$ \\
\hline & & 2 & $47.35^{A}(4.0)$ & $7.47^{A}(19.5)$ & $2.20^{A}(35.2)$ & $3.39^{A}(0.64)$ \\
\hline
\end{tabular}

Note: values in parentheses correspond to the coefficient of variation and different letters indicate statistical differences at $95 \%$ of confidence between spacings.

\section{Biomass production}

With regard to trunk biomass (ton/ha), differences between the clones were only observed in spacing $1.0 \times 1.0 \mathrm{~m}$ at 18 months, where clone 1 denoted the highest average values (Figure 3). In terms of bark biomass, the differences between clones appeared at 12 and 18 months in spacing $1.0 \times 1.0 \mathrm{~m}$ and at 24 months in spacing $1.0 \times 0.5 \mathrm{~m}$, where clone 1 was shown to have the highest values. For total biomass, differences were observed only at 18 months in spacing $1.0 \times 1.0 \mathrm{~m}$, whereas clone 1 had the highest values. Clone 2 exhibited the highest amount of biomass in spacing $0.75 \times 0.75 \mathrm{~m}$ (Figure 3 ).

The average biomass production of the clones (Figure 3 ) in the SRWC can be compared to the reports for G. arborea in Costa Rica. Tenorio et al. (2018-2019) reported a total biomass of between 25 and 65 ton/ha at the age of two years, with similar behavior relative to spacing.

An important aspect of SRWC, specifically the clones of G. arborea, was the biomass production in short spans of time (Zamora et al., 2015). According to several studies conducted in Latin America, an adequate biomass production at the age of two years in species in SRWC can range between 10 and 60 ton /ha (Moya et al., 2019; Cabrera et al., 2016; Carmona et al., 2015). Therefore, based on the results of the clones of G. arborea commonly used for wood production but planted in SRWC in different spacings (Figure 3), the production can be deemed optimum, despite the relatively low tree survival in the system.

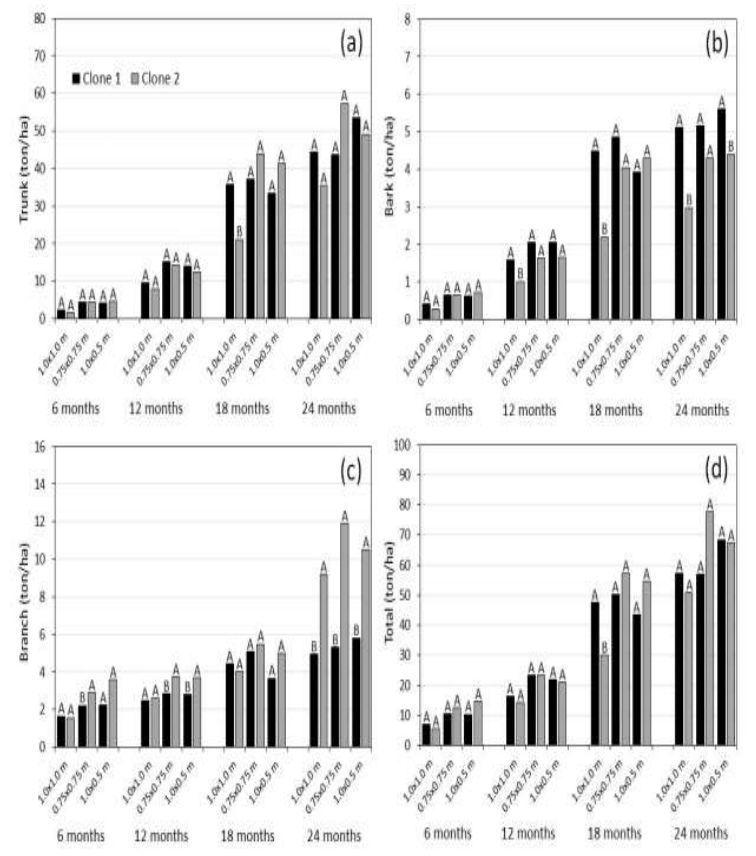

Figure 3

Average per tree piece per age and spacing in two clones of Gmelina arborea growing in a short rotation system.

Note: values in parentheses correspond to the coefficient of variation and different letters indicate statistical differences at $95 \%$ of confidence between spacings. 
Another important factor to highlight comprises of the few differences found in the biomass both in the total production, in the biomass of the different parts of trees, and at the different ages between the two clones (Figure 3). This behavior was contradictory when compared to the results of diameter development and tree height, because each clone was shown to behave differently in different spacings. Clone 1 showed appropriate productions and dasometric traits of tree for wider spacings $(1.0 \times 1.0 \mathrm{~m})$ and clone 2 for narrow spacings $(0.75 \times 0.75$ $\mathrm{m}$ and $1.0 \times 0.5 \mathrm{~m})$, which could suggest a greater production of total biomass of each clone in these spacings, something that did not occur. Importantly, the biomass values showed a very high coefficient of variation, mainly at older ages (Figure 3), which influenced the differences found between the clones (Wu et al., 2008).

As indicated in the results, in addition to height and diameter development, survival were also important when using clones. Survival was seen to influence the scarce differences found between the clones in different spacings (Figure 3 ), since in the case of narrow spacings $(0.75 \times 0.75 \mathrm{~m}$ and $1.0 \times 0.5 \mathrm{~m})$, trees tended to present better diameter development (Table 1), albeit with low survival (Figure 2c). Therefore, the height and diameter development reached by clone 2 trees in those spacings was attributed to the lower survival. Therefore, survival is an indication that some clones are genetically better suited to the conditions of competition than others (Zamora et al., 2015).

\section{Quantification of biomass by leaf fall patterns}

Biomass flow through leaf fall, measured individually per tree, showed a variation with tree aging, time of the year, spacing, and type of clone (Figure 4a-c). The amount of biomass per tree increased with age in the three spacings (Figure 4d). However, there was a variation (during the year) in these three spacings; at the end of year one, the tree reached the highest biomass elimination as the leaves fell off. After this point, biomass per leaf fall declined until the month of January, when it began to increase again until reaching a maximum point in the months of April-May (months 21-23). Then biomass per leaf fall decreased again until the $24^{\text {th }}$ month (June).

The behavior of biomass flow in the form of leaf fall is explained by the levels of rainfall reached during the year (Wright and Cornejo, 1990). This, in turn, explains the importance of knowing the distribution of precipitation in the region where these clones were planted. The months with the highest amount of precipitation begin from the second week of May continuing until August; a slight rainfall decrease follows from September to October, increasing slightly again in December. There is hardly any rainfall between January and the first week of May (Moya and Tomazello, 2008). During the first year, the biomass flow seems to be uninfluenced by precipitation, due to the dry period (Man et al., 2015). In this trial, a slight inflection point or change in the trend occurred in leaf fall during the dry months (March to May) of the first year in all spacings (Figure $4 a-c)$. Nevertheless, a constant decrease in biomass was observed in the second year, due to leaf fall, after the commencement of the dry period (after May the first year). The maximum biomass per leaf fall occurred in the second month after the rainy period started (July), when the maximum growth in Gmelina trees in Costa Rica occurred (Moya and Tomazello, 2009). The knowledge of biomass by leaf fall patterns across time and in different ages assumes significance because it can establish the sustainability of biomass production or an adequate balance of nutrients in the soil where SRWCs were planted (Griffiths et al., 2019). Although this study observed the biomass by leaf fall patterns, it did not cover the analysis of the nutrient composition of this leaf, which can help ascertain the types of nutrients that are returned to the soil. Hence, knowledge of the composition of biomass in the soil will help us establish the balance in the different ages of $G$. arborea in SRWC systems.

The spacings showed an irregular biomass flow behavior. The widest spacing $(1.0 \times 1.0 \mathrm{~m})$ exhibited higher biomass elimination by leaf fall after the age of six months, while the narrow spacing $(1.0 \times 0.5 \mathrm{~m})$ showed greater biomass elimination due to leaf fall as compared to spacing $0.75 \times 0.75 \mathrm{~m}$ (Figure $4 \mathrm{~d}$ ). This trend was observed during the period between 6 and 24 months (Figure $4 a-c$ ). To reiterate, nutritional sustainability can be improved with wider spacing because the biomass was found to be higher than narrow spacing.

Differing behaviors regarding spacing were observed in the two clones studied. With the widest spacing $(1.0 \times 1.0 \mathrm{~m})$, clone 1 showed values that were slightly above those of clone 2 after seven months, until the plantation was harvested (Figure $4 a)$. However, in the closer spacings $(0.75 \times 0.75 \mathrm{~m}$ and $1.0 \times 0.5$ $\mathrm{m})$, clone 2 presented values higher than clone 1 for the mentioned period (Figure $4 \mathrm{~b}-\mathrm{c}$ ). This behavior was confirmed in the analysis of spacings per age. At the age of six months, there was no difference between clones in different spacings, but at 12,18 and 24 months, clone 1 did exhibit biomass loss per tree statistically higher than clone 2 in spacing $1.0 \times 1.0 \mathrm{~m}$. Clone 2 shows that the biomass loss values are statistically greater than clone 1 in spacings $0.75 \times 0.75 \mathrm{~m}$ and $1.0 \times 0.5 \mathrm{~m}$ (Figure $4 \mathrm{~d}$ ). In turn, this behavior confirms the previous observation in the sense that clone 1 seems to be optimum for wide spacings and clone 2 for narrow spacings. Based on these results, the genotypes 1 of $G$. arborea was found to be better for nutritional sustainability in wider spacing and clone 2 can be better in narrow spacing, 

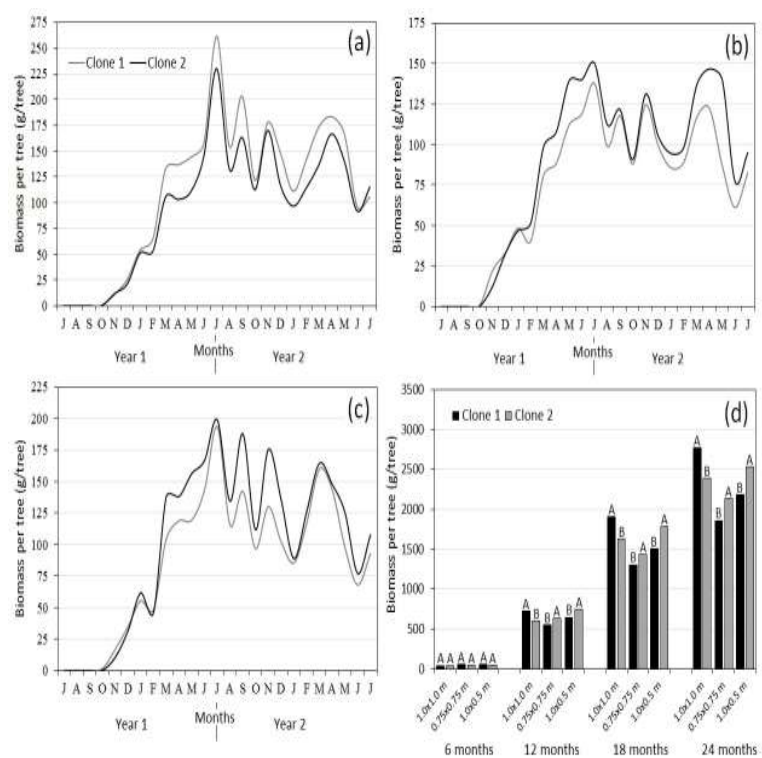

Figure 4

Biomass flow per tree during the two years of the plantation in spacings $1.0 \times 1.0 \mathrm{~m}(\mathrm{a}), 0.75 \times 0.75 \mathrm{~m}(\mathrm{~b}), 1.0 \times 0.5 \mathrm{~m}(\mathrm{c})$, and total biomass per tree per age per spacing (d).

Note: values in parentheses correspond to the coefficient of variation and different letters indicate statistical differences at $95 \%$ of confidence between spacings.

\section{Conclusion}

According to the aforementioned results derived from the first rotation trial, the trees of both clones -commonly used for the production of wood, but planted in this trial under the SRWC system- showed relevant results biomass yield in the spacings of $1.0 \times 1.0 \mathrm{~m}, 0.75 \times 0.75 \mathrm{~m} 1.0 \times 0.5 \mathrm{~m}$ under the conditions of the site studied. This spacing allowed diameter and height development and biomass production values to be comparable to the values obtained for other species under better site conditions. Both clones were studied, which are oriented to G. arborea wood production, although they were used here in a SRWC system to present the differences between the spacings. Clone 2 shows a better performance in diameter and height in closer spacings $(0.75 \times 0.75 \mathrm{~m}$ and $1.0 \times 0.5 \mathrm{~m})$, due to greater crown development. However, the yield biomass was found to be lowest, whereas clone 1 performed better in wider spacings $(1.0 \times 1.0 \mathrm{~m})$, again due to superior crown development in this spacing with higher yield biomass.

\section{Acknowledgements}

The authors wish to thank the Vicerrectoría de Investigación y Extensión of the Instituto Tecnológico de Costa Rica (ITCR) for the economic support given to this research. Many thanks also to Maderas Cultivadas de Costa Rica (MCC) for providing support in the establishment and management of the plantations.

\section{References}

Alcorn PJ, P Pyttel, J Bauhus, RGB Smith, D Thomas, R James and A Nicotra (2007) Effects of initial planting density on branch development in 4-year-old plantation grown Eucalyptus pilularis and Eucalyptus cloeziana trees. Forest Ecology and Management 252(1-3):41-51. https://doi.org/10.1016/j.foreco.2007.06.021

Arguedas M, M Rodriguez-Solis, R Moya, A Berrocal (2018) Gmelina arborea "death disease" in fast-growth plantations: effects of soil and climatic conditions on severity and incidence and its implications for wood quality. Forest Systems 27(1):003-0016. http://dx.doi.org/10.5424/fs/2018271-12236

Ávila-Arias C, R Murillo-Cruz, O Murillo-Gamboa and C Sandoval-Sandoval (2015) Desarrollo juvenil de clones de Gmelina arborea Roxb. de dos procedencias, en sitios planos del Pacífico Sur de Costa Rica. Revista Forestal Mesoamericana Kurú, 12(28): 23-35. https://doi.org/10.18845/rfmk.v12i28.2097

Ávila-Arias C, O Murillo, D Arias and R Murillo (2016) Early selection potential of Gmelina arborea Roxb. clones based on physiological correlations of their nursery-field behavior. International Journal of Applied Science and Technology 6(1):112-124

Benomar L, A DesRochers and GR Larocque (2012). The effects of spacing on growth, morphology and biomass production and allocation in two hybrid poplar clones growing in the boreal region of Canada. Trees 26:939-949. https://doi.org/10.1007/s00468-011-0671-6

Broeckx LS, SP Vanbeveren, MS Verlinden and R Ceulemans (2015) First vs. second rotation of a poplar short rotation coppice: leaf area development light interception and radiation use efficiency. iForest: Biogeosciences and Forestry 8: 565-573. https://doi.org/10.3832/ifor1457-008

Carmona R, T Nuñez and MF Alonso (2015) Biomass yield and quality of an energy dedicated crop of poplar (Populus spp.) clones in the Mediterranean zone of Chile. Biomass and Bioenergy 74:96-102. https://doi.org/10.1016/j.biombioe. 2015.01.004

Cabrera AM, C Tozzini, S Espinoza, R Santelices and F Meza (2016) Biomass production and carbon balance of a short rotation forestry of Populus deltoides (clone Lux) under two different cutting cycles. Bosque 37(1):205-210. http://dx.doi.org/10.4067/S0717-92002016000100019

Cerdá E, A Caparrós and P Ovando (2008) Bioenergía en la Unión Europea. Ekonomiaz 67:156-181

Ceulemans R, RF Stettler, TM Hinckley, JG Isebrands and PE Heilman (1990) Crown architecture of Populus clones as determined by branch orientation and branch characteristics. Tree Physiology 7:157-167. http://dx.doi.org/10.1093/treephys/7.1-2-3-4.157

Cutz L, P Haro, D Santana, and F Johnsson, (2016) Assessment of biomass energy sources and technologies: The case of Central America. Renewable Sustainable Energy Review 58:1411-1431. https://doi.org/10.1016/j.rser.2015.12.322

DeBell DS, GW Clendenen, CA Harrington and JC Zasada (1996) Tree growth and stand development in short-rotation Populus plantings: 7-year results for two clones at three spacings. Biomass and Bioenergy 11(4):253-269. https://doi.org/10.1016/0961-9534(96)00020-7

Dillen SY, SN Djomo, N Al Afas, S Vanbeveren and R Ceulemans (2013) Biomass yield and energy balance of a short-rotation poplar coppice with multiple clones on degraded land during 16 years. Biomass and bioenergy 56:157165. https://doi.org/10.1016/j.biombioe.2013.04.019

Djomo SN, A Zenone, T Ac, T De Groote, S Bergante, G Facciotto, H Sixto, P Ciria Ciria, J Wegerg and R Ceulemans (2015) Energy performances of intensive and extensive short rotation cropping systems for woody biomass production in the EU. Renewable Sustainable Energy Review 41:845-854. https://doi.org/10.1016/j.rser.2014.08.058

Dvorak WS (2004) World view of Gmelina arborea: opportunities and challenges. New Forest 28: 111-126. https://doi.org/10.1023/B:NEFO.0000040940.32574.22

Eufrade Junior HJ, RX Melo, MM Pereira Sartori, SP Sebastiao Guerra and AW Ballarin (2016) Sustainable use of eucalyptus biomass grown on short rotation coppice for bioenergy. Biomass and Bioenergy 90: 15-21. https://doi.org/10.1016/j.biombioe.2016.03.037

Fang S, X Xu, S Lu, and L Tang (1999) Growth dynamics and biomass production in short-rotation poplar plantations: 6-year results for three clones at four 
spacings. Biomass and Bioenergy 17:415-425. https://doi.org/10.1016/S0961-9534(99)00060-4

Griffiths NA, BM Rau, KB Vaché, G Starr, MM Bitew, DP Aubrey, JA Martin, E Benton, R Jackson (2019). Environmental effects of short-rotation woody crops for bioenergy: What is and isn't known. GCB Bioenergy 11(4): 554-572. https://doi.org/10.1111/gcbb.12536

Hall RB (1994) Use of the crown competition factor concept to select clones and spacings for short- rotation woody crops. Tree Physiology 14:899-909. https://doi.org/10.1093/treephys/14.7-8-9.899

Henskens F, M Battaglia, M Cherry and C Beadle (2001) Physiological basis of spacing effects on tree growth and form in Eucalyptus globulus. Trees-Struc ture and Function 15(6):365-377. https://doi.org/10.1007/s004680100114

Hegazy SS, IM Aref, H Al-Mefarrej and LI El-Juhany (2008) Effect of spacing on the biomass production and allocation in Conocarpus erectus L. trees grown in Riyadh, Saudi Arabia. Saudi Journal of Biological Science 15(2):315-322.

Inglesi-Lotz R (2016) The impact of renewable energy consumption to economic welfare: A panel data application. Energy Economics 53:58-63. https://doi.org/10.1016/j.eneco.2015.01.003

Junior HJE, RX de Melo, MMP Sartori, SPS Guerra and AW Ballarin (2016) Sustainable use of eucalypt biomass grown on short rotation coppice for bioenergy. Biomass and Bioenery 90:15-21. https://doi.org/10.1016/.j.biombioe.2016.03.037

Krebs JE (1975) A comparison of soils under agriculture and forests in San Carlos, Costa Rica. In Tropical Ecological Systems (pp. 381-390). Springer, Berlin, Heidelberg.https://doi.org/10.1007/978-3-642-88533-4_25

Laureysens I, J Bogaert, R Blust and R Ceulemans (2004) Biomass production of 17 poplar clones in a short-rotation coppice culture on a waste disposal site and its relation to soil characteristics. Forest Ecology and Management 187(2-3): 295-309. https://doi.org/10.1016/j.foreco.2003.07.005

Li Y, M Suontama, RD Burdon and HS Dungey (2017) Genotype by environment interactions in forest tree breeding: review of methodology and perspectives on research and application. Tree Genetics and Genomes 13(3):60-71. https://doi.org/10.1007/s11295-017-1144-x

Man J, Y Shi, Z Yu and Y Zhang (2015) Dry matter production, photosynthesis of flag leaves and water use in winter wheat are affected by supplemental irrigation in the Huang-Huai-Hai Plain of China. PloS one 10(9). https://doi.org/10.1371/journal.pone.0137274

Mason EG, M Diepstraten, GL Pinjuv and JP Lasserre (2012) Comparison of direct and indirect leaf area index measurements of Pinus radiata D. Don. Agricultural and Forest Meteorology 166-167: 113-119. https://doi.org/10.1016/j.agrformet.2012.06.013

Moya R, C Tenorio and G Oporto (2019) Short rotation wood crops in Latin American: A review on status and potential uses of biomass. Energies. https://doi. org/10.3390/en 12040705

Moya R and M Tomazello (2008) Variation in the wood anatomical structure of Gmelina arborea trees at different ecological conditions in Costa Rica. Revista Biología Tropical 56(2): 689-704.

Moya R and M Tomazello (2009) Wood density variation and tree ring demarcation in Gmelina arborea trees using x-ray densitometry. Cerne 15 (1): 92-100.

Murillo O, Y Badilla and SB Flores (2018) Costos de producción en ambiente protegido de clones para reforestación. Revista Forestal Mesoamericana Kurú 15(37), 15-24. https://doi.org/10.18845/rfmk.v15i37.3599

Paris P, L Mareschi, M Sabatti, A Pisanelli, A Ecosse, F Nardin and G Scarascia-Mugnozza (2011) Comparing hybrid populus clones for SRF across northern Italy after two biennial rotations: survival, growth and yield. Biomass and Bioenergy 35:1524-1532. https://doi.org/10.1016/j.biombioe.2010.12.050

Pleguezuelo CRR, VHD Zuazo, C Bielders, JAJ Bocanegra, F PereaTorres and JRF Martínez (2015) Bioenergy farming using woody crops. A review. Agronomy Sustainable Development 35(1): 95-119. https://doi.org/10.1007/s13593-014-0262-1

Roeh RL and Maguire DA (1997) Crown profile models based on branch attributes in coastal Douglas-fir. Forest Ecology and Management 96(1-2):77100. https://doi.org/10.1016/S0378-1127(97)00033-9

Ryan MG and BJ Yoder (1997). Hydraulic limits to tree height and tree growth. Bioscience 47(4):235-242. https://doi.org/10.2307/1313077

Salazar-Zeledón E, R Moya and J Valaert (2015) Biomass and bioenergy production of Arundo donax L., Pennisetum purpureum Schum. and Pennisetum purpureum Schumack. x Pennisetum glaucum L. in short rotation cropping system in Costa Rica. Journal of Biobased Material and Bioenergy 9: 572579. https://doi.org/10.1166/jbmb.2015.1562

Schulze J, K Frank, JA Priess and MA Meyer (2016) Assessing regional-scale impacts of short rotation coppices on ecosystem services by modelling landuse decisions. PloS one. 11(4):e0153862. https://doi.org/10.1371/journal.pone.0153862

Schwerz F, E Eloy, EF Elli and BO Caron (2019) Reduced planting spacing increase radiation use efficiency and biomass for energy in black wattle plantations: Towards sustainable production systems. Biomass and Bioenergy 120: 229239.https://doi.org/10.1016/j.biombioe.2018.11.034

Serrano R and R Moya (2011) Procesamiento, uso y mercado de la madera en Costa Rica: aspectos históricos y análisis crítico. Revista Forestal Mesoamericana 9(21):12-28

Stolarski MJ, S Szczukowski, J Tworkowski, H Wróblewska and M Krzyżaniak (2011) Short rotation willow coppice biomass as an industrial and energy feedstock. Industrial Crops and Products 33: 217-223. https://doi.org/10.1016/j.indcrop.2010.10.013.

Souza FC, GG dos Reis, MGF Reis, HG Leite, RS de Faria, JP Caliman, RA Barbosa and CHR de Oliveira. (2015) Growth of intact plants and coppice in short rotation eucalypt plantations. New Forests 47(2): 195-208. https://doi.org/10.1007/s11056-015-9509-1

Taylor G, R Ceulemans, R Ferris, SDL Gardner and BY Shao (2001) Increased leaf area expansion of hybrid poplar in elevated $\mathrm{CO} 2$. From controlled environments to open-top chambers and to FACE. Environmental Pollution 115:463-472. https://doi.org/10.1016/S0269-7491(01)00235-4

Tenorio C, R Moya, D Arias-Aguilar and E Briceño-Elizondo (2016) Biomass yield and energy potential of short-rotation energy plantations of Gmelina arborea one year old in Costa Rica. Industrial Crops and Products 83: 63-73. https://doi.org/10.1016/j.indcrop.2015.12.005

Tenorio C, R Moya, D Arias-Aguilar (2018) Evaluation of changes in tree morphology parameters, biomass yield, chemical and energy properties at three spacings of short rotation energy plantations of Gmelina arborea in Costa Rica, from one to two years of age. Waste and Biomass Valorization 9(7): 1163-1179. https://doi.org/10.1007/s12649-017-9896-y

Tenorio C, R Moya, E Ortiz and D Arias-Aguilar (2019) Production and regression models for biomass and carbon captured in Gmelina arborea trees in short rotation energy plantations in Costa Rica. Forest 10: 593. https://doi.org/10.3390/f10070593

Vallejos J, R Moya and R Serrano (2015) Effects of thinning on diameter, heartwood, density and drying defects of Gmelina arborea. Maderas Ciencia y Tecnología 17(2):365-372. http://dx.doi.org/10.4067/S0718-221X2015005000034

Wang YP and Jarvis PG (1990) Influence of crown structural properties on PAR absorption, photosynthesis, and transpiration in Sitka spruce: application of a model (MAESTRO). Tree Physiology 7(1-4):297-316. http://dx.doi.org/10.1093/treephys/7.1-2-3-4.297

Weiss M, F Baret, GJ Smith, I Jonckheere and P Coppin (2004) Review of methods for in situ leaf area index (LAI) determination Part II. Estimation of LAI errors and sampling. Agricultural and Forest Meteorology 121: 37-53. https://doi.org/10.1016/j.agrformet.2003.08.001

Wright SJ and FH Cornejo, F. H. (1990). Seasonal drought and leaf fall in a tropical forest. Ecology, 71(3), 1165-1175. https://doi.org/10.2307/1937384

Wu HX, M Ivkovic, WJ Gapare, AC Matheson, BS Baltunis, MB Powell and TA McRae (2008) Breeding for wood quality and profit in Pinus radiata: a review of genetic parameter estimates and implications for breeding and deployment. New Zealand Journal of Forestry Science, 38(1), 56-87.

Zamora DS, KG Apostol, WE Berguson, TA Volk, J Wright and EJ Ogdahl (2015) Short rotation woody crops biomass production. In: Biomass and biofuels: advanced biorefineries for sustainable production and distribution. Boca Raton: CRC Press, 392 p. https://doi.org/10.1201/b18398 